\title{
Editorial
}

Dermatology 2008;216:1-2

DOI: $10.1159 / 000109350$

\section{Laser and Genomics}

\author{
Manfred Kunz \\ Department of Dermatology and Venereology, University of Rostock, Rostock, Germany
}

Lasers are in widespread use in dermatology for the treatment of vascular, pigmented, precancerous, or even cancerous lesions. In particular, melanocytic skin lesions have evolved as a major area for laser treatment. However, a number of reports showed that malignant melanoma developed in such lesions previously treated by carbon dioxide or ruby lasers [1]. It could not be decided whether these lesions were melanomas in the first place, or if melanoma development was induced by laser irradiation. To address the issue of laser-induced malignant transformation, molecular genetic and gene expression analyses might be helpful. Up to now, only a limited number of reports have analyzed the biological and molecular impact of lasers on melanocytic cells, showing downregulation of different integrins, E-cadherin and TNF- $\alpha$, and upregulation of tumor suppressor p16INK4a after ruby or alexandrite laser irradiation. Overall, a more complete understanding of the molecular changes after laser treatment of melanocytic cells is still needed.

Recent progress in genomics technology enabled comprehensive genome-wide gene expression analyses of unprecedented sensitivity with quantitative detection within a wide linear range. In malignant melanoma, characteristic gene expression patterns were identified for different stages of melanoma development, different subtypes of melanomas, and tumors of different thicknesses [2-4]. Moreover, one of these studies identified gene patterns in primary tumors that correlated with the patients' prognosis [3], underscoring the diagnostic and prognostic value of molecular gene patterns. Genes identified in these studies with an apparent role in melanoma development and progression included different cyclins, cyclindependent kinases such as CDK1, cell adhesion molecules, minichromosome maintenance genes, and cancertestis antigens.

There is a very limited number of studies combining laser application with global gene expression analyses. It has been shown that in vitro irradiation of human fibroblasts with a low-intensity red light laser, generally used for tissue repair and remodeling, significantly induced gene expression involved in cell proliferation and apoptosis inhibition [5]. Among these were CDK5 and platelet-derived growth factor C. In a similar approach using a low intensity laser of a different wavelength for irradiation of a mouse osteoblastic cell line, the osteoinducing factor osteoglycin showed prominent upregulation [6]. In ophthalmology, lasers have been used successfully for the treatment of different forms of neovascularization. In an experimental approach, short- and long-term effects of argon laser photocoagulation on gene expression patterns were analyzed in the posterior mouse eye $[7,8]$. Authors showed upregulation of genes involved in cell structure, tissue repair, cell migration, and angiogenesis. Among these were different types of crystallins and thrombospondin 1. It was suggested that modulated gene expression might contribute to both short- and long-term effects in laser treated microangiopathies.

In an elegant approach published in this issue of Dermatology, Hafner and coworkers analyzed gene expression patterns of melanocytes after Q-switched ruby laser

\section{KARGER \\ Fax +4161306 1234}

E-Mail karger@karger.ch

www.karger.com
(C) 2008 S. Karger AG, Basel

$1018-8665 / 08 / 2161-0001 \$ 24.50 / 0$

Accessible online at:

www.karger.com/drm
Manfred Kunz, MD

Department of Dermatology and Venereology, University of Rostock Augustenstrasse 80

DE-18055 Rostock (Germany)

Tel. +49381 4949 708, E-Mail manfred.kunz@med.uni-rostock.de 
irradiation [9]. The authors demonstrated differential expression of a limited number of 31 genes, out of a total of more than 14,000 tested. None of these genes had been reported before to be directly linked to tumor development or progression of malignant melanoma, suggestive of a minor effect of ruby lasers on benign melanocytes. However, gene expression patterns only reflect part of the spectrum of molecular changes, because genomic alterations such as mutations and gene and chromosomal amplifications are widespread in cancer. Therefore, further genetic analyses are required to understand the full spectrum of molecular changes after laser treatment. These analyses might be facilitated by findings presented in a very recent report, analyzing 238 oncogene mutations in a large series of different cancers including malignant melanoma [10]. Also, in vivo studies should be performed, since the tissue microenvironment has an important impact on local gene expression.

Taken together, large-scale gene expression and genetic studies using current genomics technologies might help to estimate the oncogenic potential induced in melanocytic cells after laser treatment. Safety issues might appear in a new light and support the development of new treatment guidelines.

\section{References}

1 Gottschaller C, Hohenleutner U, Landthaler M: Metastasis of a malignant melanoma 2 years after carbon dioxide laser treatment of a pigmented lesion: case report and review of the literature. Acta Derm Venereol 2006;86: 44-47.

2 Haqq C, Nosrati M, Sudilovsky D, Crothers J, Khodabakhsh D, Pulliam BL, Federman S, Miller JR 3rd, Allen RE, Singer MI, Leong SP, Ljung BM, Sagebiel RW, Kashani-Sabet M: The gene expression signatures of melanoma progression. Proc Natl Acad Sci USA 2005; 102:6092-6097.

3 Winnepenninckx V, Lazar V, Michiels S, Dessen P, Stas M, Alonso SR, Avril MF, Ortiz Romero PL, Robert T, Balacescu O, Eggermont AM, Lenoir G, Sarasin A, Tursz T, van den Oord JJ, Spatz A: Gene expression profiling of primary cutaneous melanoma and clinical outcome. J Natl Cancer Inst 2006;98: 472-482.
4 Jaeger J, Koczan D, Thiesen HJ, Ibrahim SM, Gross G, Spang R, Kunz M: Gene expression signatures for tumor progression, tumor subtype, and tumor thickness in laser-microdissected melanoma tissues. Clin Cancer Res 2007;13:806-815.

5 Zhang Y, Song S, Fong CC, Tsang CH, Yang $Z$, Yang M: cDNA microarray analysis of gene expression profiles in human fibroblast cells irradiated with red light. J Invest Dermatol 2003;20:849-857.

6 Hamajima S, Hiratsuka K, Kiyama-Kishikawa M, Tagawa T, Kawahara M, Ohta M, Sasahara H, Abiko Y: Effect of low-level laser irradiation on osteoglycin gene expression in osteoblasts. Lasers Med Sci 2003;18:78-82.

7 Binz N, Graham CE, Simpson K, Lai YK, Shen WY, Lai CM, Speed TP, Rakoczy PE: Long-term effect of therapeutic laser photocoagulation on gene expression in the eye. FASEB J 2006;20:383-385.

8 Wilson AS, Hobbs BG, Shen WY, Speed TP, Schmidt U, Begley CG, Rakoczy PE: Argon laser photocoagulation-induced modification of gene expression in retina. Invest Ophthalmol Vis Sci 2003;44:1426-1434.
9 Hafner C, Stempfl T, Baeumler W, Hohenleutner U, Landthaler M, Vogt T: Gene expression profiling of melanocytes following Q-switched ruby laser irradiation. Dermatology 2008;216:6-13.

10 Thomas RK, Baker AC, Debiasi RM, Winckler W, Laframboise T, Lin WM, Wang $M$, Feng W, Zander T, Macconnaill LE, Lee JC, Nicoletti R, Hatton C, Goyette M, Girard L, Majmudar K, Ziaugra L, Wong KK, Gabriel S, Beroukhim R, Peyton M, Barretina J, Dutt A, Emery C, Greulich H, Shah K, Sasaki H, Gazdar A, Minna J, Armstrong SA, Mellinghoff IK, Hodi FS, Dranoff G, Mischel PS, Cloughesy TF, Nelson SF, Liau LM, Mertz K, Rubin MA, Moch H, Loda M, Catalona W, Fletcher J, Signoretti S, Kaye F, Anderson KC, Demetri GD, Dummer R, Wagner S, Herlyn M, Sellers WR, Meyerson M, Garraway LA: High-throughput oncogene mutation profiling in human cancer. Nat Genet 2007;3:347-351. 